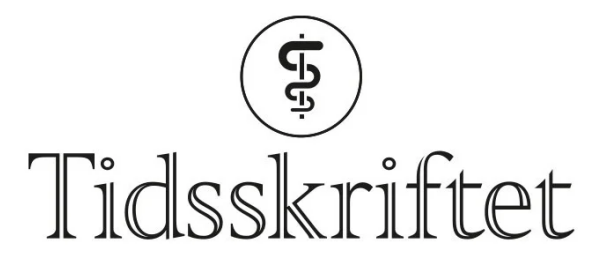

DEN NORSKE LEGEFORENING

\title{
Krav til kvalitetskontroll av kirurgi
}

DEBATT

\section{JAN LUDVIG SVENNEVIG}

janlsvennevig@ymail.com

Jan Ludvig Svennevig er tidligere overlege, avdelingsleder og professor ved Thoraxkirurgisk avdeling, Oslo universitetssykehus. Som pensjonist har han arbeidet med IT og kvalitetssikring.

Forfatteren har fylt ut ICMJE-skjemaet og oppgir følgende interessekonflikter: Han er rettighetshaver til Datacor.

\section{Kvalitetssikring av kirurgiske inngrep og intervensjoner forutsetter egnet verktøy og nødvendige ressurser.}

Ikke sjelden finner vi sensasjonelle oppslag i norske medier om mangelfull kvalitet ved enkelte sykehusavdelinger, noen ganger knyttet til enkelte kirurger. En kirurgisk avdeling bør derfor til enhver tid ha full oversikt over aktivitet, type inngrep, risikofaktorer og resultater (dødsfall, komplikasjoner, liggetider etc.), slik at ledelsen kan gjennomgå uheldige hendelser. Det meste av denne informasjonen krever strukturerte data som i dag ikke enkelt kan hentes ut fra pasientadministrative systemer eller journaler. Det er heller ikke mulig å registrere alle risikofaktorer eller komplikasjoner med ICD-1o-koder eller med nasjonale prosedyrekoder (1). Enkelte ønsker å gjøre journalen strukturert (ㅁ), andre vil hente ut strukturerte data fra tekst ved hjelp av kunstig intelligens (3). Det forutsetter at de etterspurte data er beskrevet i teksten.

\section{Tidkrevende registrering}

Dette er ingen ny problemstilling. Fram til begynnelsen av 1980-årene ble aktivitetsdata oftest hentet ut manuelt fra operasjonsprotokollene. Ved å telle gjentatte ganger kunne man hente ut informasjon om antall inngrep, stuer, operatører og team og på den måten lage årsrapporter og operasjonslister for kandidater som trengte dokumentasjon etc.

Som torakskirurg ved Rikshospitalet tok jeg for over 30 år siden initiativ til å starte et utvidet register kalt Datacor (4). Databasen inneholdt både risikofaktorer, tekniske operasjonsdata og resultater, og registreringen ble utført strukturert av helsepersonell både før, under og etter operasjon. Datacor leverte i perioden 1989-2016 månedlige aktivitets- og kvalitetsrapporter. I tillegg ble data levert til Norsk hjertekirurgiregister (5) og European Adult Cardiac Surgical Database (ㅁ). 
Selve registreringen er tidskrevende. Registreringen bør derfor begrenses til det nødvendige. Det er lite motiverende å registrere data som ikke blir brukt. Min erfaring er at man bør starte med en minimumsdatabase og heller legge til flere elementer ved behov. Selve registreringen bør, basert på eksakt definering av faktorene, begrense seg til et ja (i et logisk felt) eller 1-tall (i et numerisk felt). Erfaringsmessig blir ikke registreringen bedre av å tvinge registeransvarlig til å svare nei på 20-30 felt. Valg av risikofaktorer og kvalitetsindikatorer vil variere fra fag til fag. Helsedirektoratet har utviklet et utmerket sett med indikatorer for en rekke fagområder og har definert disse (7.). Databaseprogrammet bør også automatisk kunne sjekke alder, kjønn (niende siffer i personnummer) samt beregne kroppsmasseindeks, kroppsoverflate, nyrefunksjon (kreatinin-clearance), risikoskår og om ønskelig DRG-kode.

Mange kolleger ønsker å bruke enklere databaser hvor man selv kan foreta analyser og lage rapporter. Sykehuseierne ønsker oftest sentral lagring av store datamengder ( $\underline{8}$ ). God tilgangskontroll og sikker lagring er sannsynligvis av større betydning enn valg av database. Uansett plattform må de nye databasene være i stand til å møte de europeiske kravene til datalagring (9).

\section{Kvalitetskontroll bør bli et krav}

Vår database ble utviklet fordi det ikke fantes kommersielt tilgjengelig programvare. Alle avdelinger som utfører kirurgiske inngrep eller intervensjoner, bør ha en kvalitetsdatabase som gir behandlere og ledelse anledning til kontinuerlig overvåkning av resultater. Kvalitetsdatabasen kan være en strukturert del av journalen.

Mange avdelinger har erfaring med kvalitetsovervåkning over lang tid, men når disse (ofte egenutviklede) systemene etter hvert avvikles, bør man ta med erfaringene inn i det videre arbeidet. Det er ikke slik at selv om noe er nytt, så er det nødvendigvis bedre. Fortsatt utføres det operasjoner og intervensjoner i Norge uten adekvat og fortløpende kvalitetskontroll. Kvalitetskontroll bør bli et krav. Men kvalitetskontroll krever ressurser. Mye av kvalitetsarbeidet som over årtier er utført gratis av entusiastiske ansatte, vil bli faset ut og erstattet av nye systemer. Det vil koste.

\section{LITTERATUR}

1. Direktoratet for e-helse. NCMP, NCSP og NCRP. Norsk klinisk prosedyrekodeverk. https://finnkode.ehelse.no. Lest 26.3.2021.

2. Helse Nord. Strukturert journal. https://helse-nord.no/fresk/strukturert-journal Lest 26.3.2021.

3. Helse Sør- $\emptyset$ st. Kunstig intelligens kan redde liv. https://www.helse-sorost.no/nyheter/kunstigintelligens-kan-redde-liv Lest 26.3.2021.

4. Svennevig JL, Bech J, Karlsen H et al. Fra virksomhetsregistrering til klinisk informasjonssystem. Utvikling av Datacor-systemet ved Kirurgisk avdeling A, Rikshospitalet. Tidsskr Nor Lægeforen 1995; 115: 1057-9. [PubMed]

5. Svennevig JL, Segadal L, Haverstad R. Hjertekirurgiregisteret og fagmiljøene. Tidsskr Nor Legeforen 2011; 131:38-40. [PubMed][CrossRef]

6. Keogh BE, Walton PKH, Kinsman R. The European Association for Cardio-Thoracic Surgery. Third European Adult Cardiac Surgical Database Report. Oxfordshire: Dendrite Clinical Systems, 2007.

7. Helsedirektoratet. Kvalitetsindikatorer (NKI).

https://www.helsedirektoratet.no/statistikk/kvalitetsindikatorer Lest 26.3.2021.

8. Direktoratet for e-helse. Akson. https://ehelse.no/tema/akson Lest 26.3.2021. 

Lest 26.3.2021.

Publisert: 23. april 2021. Tidsskr Nor Legeforen. DOI: 10.4045/tidsskr.21.0149

Mottatt 23.2.2021, første revisjon innsendt 13.3.2021, godkjent 26.3.2021.

(C) Tidsskrift for Den norske legeforening 2023. Lastet ned fra tidsskriftet.no 26. april 2023. 